\title{
MODEL PEMBELAJARAN KONSTRUKTIVISME
}

\author{
Nur Risma Khafifah ${ }^{1}$ \\ ${ }^{1}$ Jurusan Pendidikan Fisika FKIP Universitas Siliwa \\ ngi, Tasikmalaya Jawa Barat Indonesia \\ Email : nurrisma8816@gmail.com, dwi.sulistyaningsih@unsil.ac.id
}

\begin{abstract}
Abstrak
Constructivism is a learning model that emphasizes the current activities of students in every interaction that can be instructive in exploring and finding their own knowledge. This flow of constructivism, in the study of education is a developing flow of theoretical cognitive psychology which emphasizes students to be able to play an active role in discovering new knowledge. This research is a literature study, namely research based on studies from various sources. Data from literature are collected and analyzed to present the results and discussion to draw conclusions.
\end{abstract}

\begin{abstract}
Abstrak
Kontruktivisme merupakan model pembelajaran yang menekankan pada aktivitas terkini siswa dalam setiap interaksi dapat bersifat instruktif untuk menggali dan menemukan ilmunya sendiri. Aliran konstruktivisme ini, dalam kajian ilmu pendidikan adalah aliran yang berkembang Psikologi kognitif teoritis yang menekankan pada siswa untuk dapat memainkan suatu peran atif dalam menemukan pengetahuan baru.Penelitian ini merupakan penelitian study pustaka, yaitu penelitian berdasarkan kajian dari berbagai sumber. Data dari literature yang dikumpulkan dan dianalisis untuk disajikan dalam hasil dan diskusi untuk menarik kesimpulan.
\end{abstract}

Belajar merupakan hasil dari pengalaman atau latihan yang diperkuat yang terjadi akibat suatu perubahan yang relatif permanen dalam perilaku atau potensi perilaku. Belajar merupakan akibat adanya interaksi antara stimulus dan respons. Seseorang dianggap telah belajar sesuatu jika dia dapat menunjukkan perubahan perilakunya. Sedangkan pembelajaran merupakan suatu proses yang dilakukan dengan memberikan pendidikan dan pelatihan kepada peserta didik untuk mencapai hasil belajar.

Pada era saat ini terdapat beragam inovasi baru di dalam dunia pendidikan terutama pada proses pembelajaran. Salah satu inovasi tersebut adalah konstruktivisme. Pemilihan pendekatan ini lebih dikarenakan agar pembelajaran membuat siswa antusias terhadap persoalan yang ada sehingga mereka mau mencoba memecahkan persoalannya. Pembelajaran di kelas masih dominan menggunakan metode ceramah dan tanya jawab sehingga kurang memberikan kesempatan kepada siswa untuk berintekrasi langsung kepada benda-benda konkret.

Seorang guru haruslah memperhatikan konsep awal siswa sebelum pembelajaran. Jika tidak demikian, maka seorang pendidik tidak akan berhasil menanamkan konsep yang benar, bahkan dapat memunculkan sumber kesulitan belajar selanjutnya. Mengajar bukan hanya untuk meneruskan gagasangagasan pendidik pada siswa, melainkan sebagai proses mengubah konsepsi-konsepsi siswa yang sudah ada dan di mana mungkin konsepsi itu salah, dan jika ternyata benar maka pendidik harus membantu siswa dalam mengkonstruk konsepsi tersebut biar lebih matang.

Oleh karena itu, guru harus menyediakan dan memberikan kesempatan sebanyak mungkin kepada siswa untuk belajar secara aktif. Sedemikian rupa sehingga para siswa dapat menciptakan, membangun, mendiskusikan, membandingkan, bekerja sama, dan melakukan eksperimentasi dalam kegiatan belajarnya (Setyosari, 1997: 53).

\section{Pengertian Model Konstruktivisme}


Konstruktivisme berasal dari kata konstruktiv dan isme. Konstruktiv berarti bersifat membina, memperbaiki, dan membangun. Sedangkan Isme dalam kamus Bahasa Inonesia berarti paham atau aliran. Konstruktivisme merupakan aliran filsafat pengetahuan yang menekankan bahwa pengetahuan kita merupakan hasil konstruksi kita sendiri (von Glaserfeld dalam Pannen dkk, 2001:3).

Konstruktivisme memiliki arti dasar yaitu membangun. Dimana yang kata dibangun ini adalah konsep/materi yang akan dipelajari, yang mana konsep tesebut dibangun oleh guru dan siswa dalam proses pembelajaran. Model pembelajaran kostruktivisme di sini berarti suatu cara dimana individu atau anak didik tidak sekedar mengimitasi dan membentuk bayangan dari apa yang diamati atau yang diajarkan guru, tetapi secara aktif individu atau anak didik itu menyeleksi, menyaring, memberi arti dan menguji kebenaran atas informasi yang diterimanya.

Konstruktivisme adalah sebuah teori yang memberikan kebebasan terhadap manusia yang ingin belajar atau mencari kebutuhannya dengan kemampuan untuk menemukan keinginan atau kebutuhannya dengan bantuan fasilitasi orang lain.Kontruksi berarti bersifat membangun, dalam konteks filsafat pendidikan, Konstruktivisme adalah suatu upaya membangun tata susunan hidup yang berbudaya modern. Konstruktivisme merupakan landasan berfikir (filosofi) pembelajaran konstektual yaitu bahwa pengetahuan dibangun oleh manusia sedikit demi sedikit, yang hasilnya diperluas melalui konteks yang terbatas dan tidak sekonyong-konyong. Pengetahuan bukanlah seperangkat fakta-fakta, konsep, atau kaidah yang siap untuk diambil dan diingat. Manusia harus mengkontruksi pengetahuan itu dan memberi makna melalui pengalaman nyata.

Pendekatan konstruktivisme mempunyai beberapa konsep umum seperti:

1. Pelajar aktif membina pengetahuan berasaskan pengalaman yang sudah ada.

2. Dalam konteks pembelajaran, pelajar seharusnya membina sendiri pengetahuan mereka.

3. Pentingnya membina pengetahuan secara aktif oleh pelajar sendiri melalui proses saling mempengaruhi antara pembelajaran terdahulu dengan pembelajaran terbaru.

4. Unsur terpenting dalam teori ini ialah seseorang membina pengetahuan dirinya secara aktif dengan cara membandingkan informasi baru dengan pemahamannya yang sudah ada.

5. Ketidakseimbangan merupakan faktor motivasi pembelajaran yang utama. Faktor ini berlaku apabila seorang pelajar menyadari gagasan-gagasannya tidak konsisten atau sesuai dengan pengetahuan ilmiah.

6. Bahan pengajaran yang disediakan perlu mempunyai perkaitan dengan pengalaman pelajar untuk menarik minat pelajar.

Teori Konstruktivistik memandang bahwa belajar adalah mengonstruksi makna atas informasi dan masukan-masukan yang masuk ke dalam otak. Belajar yang bersifat konstruktif ini sering digunakan untuk menggambarkan jenis belajar yang terjadi selama penemuan ilmiah dan pemecahan masalah kreatif di dalam kehidupan sehari-hari. Pada teori ini juga memandang peserta didik sebagai individu yang selalu memeriksa informasi baru yang berlawanan dengan prinsip-prinsip yang telah ada dan merevisi prinsipprinsip tersebut apabila sudah dianggap tidak dapat digunakan lagi. Hal ini memberikan implikasi bahwa peserta didik harus terlibat aktif dalam kegiatan pembelajaran.

Dengan demikian, belajar menurut teori konstruktivisme bukanlah sekadar menghafal, akan tetapi proses mengkonstruksi pengetahuan melalui pengalaman. Pengetahuan bukanlah hasil "pemberian" dari orang lain seperti guru, akan tetapi hasil dari proses mengkonstruksi yang dilakukan setiap individu. Pengetahuan hasil dari "pemberian" tidak akan bermakna. Adapun pengetahuan yang diperoleh melalui proses mengkonstruksi pengetahuan itu oleh setiap individu akan memberikan makna mendalam atau lebih dikuasai dan lebih lama tersimpan/diingat dalam setiap individu.

\section{Konsep Model Pembelajaran Konstruktivisme}

Dalam model pembelajaran konstruktivisme terdapat beberapa konsep, sebagai berikut:

1. Konstruktivisme Individu

Pandangan ini fokus pada kehidupan manusia, yakni mengartikan sesuatu dengan menggunakan pengetahuan dan keyakinannya secara individu. Pengetahuan disusun dengan mentransformasikan, 
mengorganisasi, dan mengeorganisasikan pengetahuan yang sebelumnya. Piaget menekankan pada hal-hal yang masuk akal dan konstruksi pengetahuan yang tidak biasa secara langsung dipelajari dari lingkungan. Pengetahuan muncul dari merefleksikan dan menghubungkan kognisi atau pikiran-pikiran kita sendiri, bukan dari pemetaan realitas eksternal. Piaget melihat lingkungan sosial sebagai sebuah faktor penting dalam pengembangan kognisi, tapi dia tidak meyakini bahwa interaksi sosial merupakan mekanisme utama dalam mengubah pikiran.

Piaget mengusulkan tahapan kognitif yang dilakukan oleh semua manusia. Berpikir pada tiap langkah memasukkan tahapan sebelumnya sehingga makin terorganisir dan adaptif. Piaget menjelaskan bagaimana tiap individu mengembangkan schema, yaitu suatu sistem organisasi aksi atau pola pikir yang membuat kita secara mental mencerminkan "berpikir mengenainya". Dua proses diaplikasikan dalam hal ini yaitu asimilasi dan akomodasi. Melalui asimilasi kita berusaha memahami hal yang baru dengan mengaplikasikan schema yang ada; sedangkan akomodasi terjadi ketika seseorang harus merubah pola berpikirnya untuk merespon terhadap situasi yang baru. Seseorang melakukan adaptasi dalam situasi yang makin kompleks ini dengan menggunakan schema yang masih bisa dianggap layak (asimilasi) atau dengan melakukan perubahan dan menambahkan pada schemanya sesuatu yang baru karena memang diperlukan (akomodasi).

Hal yang paling mendasar dari penemuan Piaget ini adalah belajar pada siswa tidak harus terjadi hanya karena seorang guru mengajarkan sesuatu padanya, Piaget percaya bahwa belajar terjadi karena siswa memang mengkonstruksi pengetahuan secara aktif darinya, dan ini diperkuat bila siswa mempunyai kontrol dan pilihan tentang hal yang dipelajari. Hal ini tidaklah meniadikan faktor guru dalam proses pembelajaran, justru sebaliknya lah yang terjadi. Pengajaran oleh guru yang mengajak siswa untuk bereksplorasi, melakukan manipulasi, baik dalam bentuk fisik atau secara simbolik, bertanya dan mencari jawaban, membandingkan jawaban dari siswa lain akan lebih membantu siswa dalam belajar dan memahami sesuatu.

2. Konstruktivisme Sosial

Vygotsky meyakini bahwa interaksi sosial, unsur-unsur budaya, dan aktivitasnya adalah yang membentuk pengembangan dan pembelajaran individu. Atau dengan kata lain, pengetahuan disusun berdasarkan interaksi sosial dalam konteks sosial budayanya. Penemuan yang terencana, pengajaran, model dan pelatihan, seperti juga pengetahuan, keyakinan dan pemikiran siswa, mempengaruhi pembelajaran.

Di dalam konsep Vygotsky ada tingkatan pengetahuan atau pengetahuan berjenjang yang disebut scaffolding. Scaffolding berarti memberikan kepada seorang individu sejumlah besar bantuan selama tahap-tahap awal pembelajaran dan kemudian mengurangi bantuan tersebut dan memberikan kesempatan kepada anak tersebut mengambil alih tanggungjawab yang semakin besar segera setelah mampu mengerjakan sendiri. Bantuan yang diberikan pembelajar dapat berupa petunjuk, peringatan, dorongan, menguraikan masalah ke dalam bentuk lain yang memungkinkan siswa dapat mandiri.

Vygotsky mengemukakan tiga kategori pencapaian siswa dalam upaya memecahlan permasalahan, yaitu:

1. siswa mencapai keberhasilan dengan baik,

2. siswa mencapai keberhasilan dengan bantuan,

3. siswa gagal meraih keberhasilan.

Para konstruktivis Vygotsky lebih menekankan pada penerapan teknik saling tukar gagasan antar individual. Terdapat dua prinsip penting yang diturunkan dari teori Vygotsky, yakni:

1. Mengenai fungsi dan pentingnya bahasa dalam komunikasi sosial yang dimulai proses pengindraan terhadap tanda sampai kepada tukar menukar informasi dan pengetahuan,

2. Zona of Proximal Develpment (ZPD). Pendidik sebagai mediator memiliki peran mendorong dan menjembatani siswa dalam upaya membangun pengetahuan, pengertian, dan kompetensinya.

Dalam interaksi sosial di kelas, ketika terjadi saling tukar pendapat antar siswa dalam memecahkan suatu masalah, siswa yang lebih pandai memberi bantuan kepada siswa yang mengalami kesulitan berupa petunjuk bagaimana cara memecahkan masalah tersebut, maka terjadi scaffolding, 
siswa yang mengalami kesulitan tersebut terbantu oleh teman yang lebih pandai. Ketika guru membantu secukupnya kepada siswa yang mengalami kesulitan dalam belajarnya, maka terjadi scaffolding.

Konsep zona of proximal development (ZPD) menurut Vygotsky berdasar pada ide bahwa perkembangan pengetahuan siswa ditentukan oleh dua hal, yaitu apa yang dapat dilakukan oleh siswa sendiri dan apa yang dilakukan oleh siswa ketika mendapat bantuan orang yang lebih dewasa atau teman sebaya yang berkompeten.

\section{Kelebihan Model Konstruktivisme}

Hidup ini, tidak ada yang sempurna ada kebaikan ada juga keburukan, begitu juga dengan sebuah teori. Tidak ada teori yang sempurna akan tetapi saling melengkapi antara yang satu dengan yang lainya begitu juga konstruktivisme. Adapun kelebihan dari teori konstruktivisme diantaranya :

Pertama, guru bukan satu-satunya sumber belajar. Maksud dari kata tersebut adalah dalam proses pembelajaran guru hanya sebagai pemberi ilmu dalam pembelajaran, siswa tuntut untuk lebih aktif dalam proses pembelajarannya, baik dari segi latihan, bertanya, praktik dan lain sebagainya, jadi guru hanya sebagi pemberi arah dalam pembelajaran dan menyediakan apa-apa saja yang dibutuhkan oleh siswanya. Sebab dalam kosntruktivisme pengetahuan itu tidak hanya di dapatkan dalam proses pembelajaran akan tetapi bisa juga di dapatkan melalui diskusi, pengalaman dan juga bisa di dapatkan di lingkungan sekitarnya.

Kedua, siswa (pembelajaran) lebih aktif dan kreatif. Maksudnya di mana siswa dituntut untuk bisa memahami pembelajarannya baik di dapatkan di sekolah dan yang dia dapatkan di luar sekolah, sehingga pengetahuan-pengetahuannya yang dia dapatkan tersebut bisa dia kaitkan dengan baik dan seksama, selain itu juga siswa di tuntut untuk bisa memahami ilmu-ilmu yang baru dan dapat di koneksikan dengan ilmuilmu yang sudah lama.

Ketiga, pembelajaran menjadi lebih bermakna. Belajar bermakna berarti menginstrksi informasi dalam struktur penelitian lainnya. Artinya pembelajaran tidak hanya mendengarkan dari guru saja akan tetapi siswa harus bisa mengaitkan dengan pengalaman-pengalaman pribadinya dengan informasiinformasi yang dia dapatkan baik dari temanya, tetangganya, keluarga, surat kabar, televisi, dan lain sebagainya.

Keempat, pembelajaran memiliki kebebasan dalam belajar. Dimana siswa bebas mengaitkan ilmuilmu yang dia dapatkan baik di lingkungannya dengan yang di sekolah sehingga tercipta konsep yang diharapkannya. Kelima, perbedaan individual terukur dan di hargai. Keenam, guru berfikir proses membina pengetahuan baru, siswa berfikir untuk menyelesaikan masalah, dan membuat keputusan.

\section{Kekurangan Model Konstruktivisme}

Pertama, proses belajar konstruktivisme secara konseptual adalah proses belajar yang bukan merupakan perolehan informasi yang berlangsung satu arah dari luar ke dalam diri siswa kepada pengalamannya melalui proses asimilasi dan akomodasi yang bermuara pada pemutakhiran sruktur kognitif. Kedua, peran siswa. Menurut pandangan ini, belajar merupakan suatu proses pembentukan pengetahuan. Ketiga, peran guru. Dalam pendekatan ini guru atau pendidik berperan membantu agar proses pengonstruksian pengetahuan oleh siswa berjalan lancar. Guru tidak menerapkan pengetahuan yang telah dimilikinya, melainkan membantu siswa untuk membentuk pengetahuannya sendiri.

Keempat, sarana belajar. Pendekatan ini menekankan bahwa peran utama dalam kegiatan belajar adalah aktifitas siswa dalam mengonstruksi pengetahuannya sendiri. Kelima, evaluasi, pandangan ini mengemukakan bahwa lingkungan belajar sangat mendukung munculnya berbagai pandangan dan interpretasi terhadap realitas, konstruksi pengetahuan, serta aktifitas-aktifitas lain yang didasarkan pada pengalaman.

\section{KESIMPULAN}


Pembelajaran konstruktivisme adalah sebuah model pembelajaran yang memberikan kesempatan kepada siswa untuk menjadi kreatif dan melakukan berbagai aktifitas di dalam berbagai interaksi edukatif untuk dapat melakukan eksplorasi dan dapat menemukan pengetahuannya sendiri. Konstruktivisme berasumsi bahwa setiap peserta didik mulai dari sejak usia kanak-kanak sampai menginjak jenjang Perguruan Tinggi telah memiliki gagasan atau pengetahuan tentang lingkungannya dan peristiwa-peristiwa yang terjadi di lingkungan sekitarnya. Pembelajaran Konstruktivisme memungkinkan tersedianya kesempatan yang lebih banyak untuk keterlibatan siswa di dalam kelas secara aktif, melakukan eksplorasi, serta menggali secara lebih dalam potensi atau kemampuan baik secara kognitif afektif maupun psikomotor. Dalam model konstruktivisme siswa tidak diindoktrinasi, akan tetapi mereka menemukan sendiri dan mengeksplorasi pengetahuan tersebut dengan apa yang telah mereka ketahui dan pelajari sendiri.

Terdapat dua konsep model pembelajaran konstruktivisme yaitu konstruktivisme individu dan konstruktivisme sosial. Kelebihan dalam model pembelajaran guru bukan satu-satunya sumber belajar, siswa (pembelajaran) lebih aktif dan kreatif, pembelajaran menjadi lebih bermakna, dan pembelajaran memiliki kebebasan dalam belajar. Kekurangan dalam model pembelajaran konstruktivisme yaitu proses belajar konstruktivisme secara konseptual, proses pembentukan pengetahuan, dan pendidik berperan membantu agar proses pengonstruksian pengetahuan oleh siswa berjalan lancar.

\section{UCAPAN TERIMA KASIH}

Terima kasih kepada semua pihak yang telah membantu dalam penyelesaian artikel ini menjadi lebih baik.

\section{DAFTAR PUSTAKA}

Aqib, Z. 2002. Profesionalisme Guru Dalam Pembelajaran. Surabaya : Insan Cendikia.

Budiningsih, C.A. 2005. Belajar dan Pembelajaran. Jakarta : Rineka Cipta.

Mashudi dkk. 2013. Desain Model Pembelajaran Inovatif Berbasis Konstruktivisme. Tulungagung: STAIN Tulungagung Press.

Muhibbin Syah. 1999. Psikologi Pendidikan dengan Pendekatan Baru. Bandung: Remaja RosdaKarya.

Robert Slavin. 2011. Psikologi Pendidikan Teori dan Praktik. Jakarta: PT. Indeks 